\title{
ECONOMIC FREEDOM: LOOKING FOR ANSWERS IN THE ENTREPRENEURIAL ACTIVITY
}

\author{
https://doi.org/10.47743/jopafl-2021-21-03
}

\author{
Anca Elena LUNGU \\ Alexandru Ioan Cuza University of Iași \\ Faculty of Economics and Business Administration \\ ancalungu01@gmail.com \\ Gabriel Claudiu MURSA \\ Alexandru Ioan Cuza University of Iași \\ Faculty of Economics and Business Administration \\ gabriel.mursa@gmail.com
}

\begin{abstract}
The entrepreneur fires up the market mechanism through his actions or, in other words, is the driving force of the market process. However, in order to carry out the entrepreneurial activity and to enjoy a competitive market, it is clearly necessary to have a stable framework, based on freedom. The question is: how can economic freedom influence the entrepreneurial activity? To answer this question, we seek to identify and demonstrate (once again) the link between economic freedom and entrepreneurship. Economic freedom explains some aspects at the level of governmental influence on the economic activity, taxes on entrepreneurial activity, property rights, openness to international trade, the monetary system, etc. All these dimensions are focused on the way institutions exercise their influence on the rules of the game. A literature review was undertaken, and quantitative analysis techniques were used to achieve the abovementioned objective. Looking back, history proved that human evolution is based on the principles of freedom, regardless of the form it may take. Consistent with most of the studies available in the literature, we can conclude that countries with a high degree of economic freedom champion entrepreneurial activities. Economic freedom provides individuals that have entrepreneurial skills with the opportunity to act for a potential profit. Alternatively, (any kind of) restricted freedom causes changes in the behaviour of individuals and, by extension, in the activities of entrepreneurs.
\end{abstract}

Keywords: entrepreneurship, economic freedom, free market

JEL Classification: F02, F20, L26

This Article was presented as a paper at the $13^{\text {th }}$ edition of the Annual International Conference Globalization and Higher Education in Economics and Business Administration (GEBA 2021), which was held at the Alexandru Ioan Cuza University, Faculty of Economics and Business Administration in Iasi, Romania from the $21^{\text {st }}$ to $23^{\text {rd }}$ of October 2021.

\section{Introduction}

The differences between the levels of economic development among countries have been of interest in the specialty literature and, most of the times, have been explained by different degrees of economic freedom. Subsequently, these have also been explained by differences in the level of entrepreneurship. Under such conditions, we seek to exemplify 
the connection between economic freedom and entrepreneurial activity in 11 postcommunist countries that are now part of the European Union, namely: Bulgaria, Croatia, the Czech Republic, Estonia, Hungary, Latvia, Lithuania, Poland, Romania, Slovakia, and Slovenia. Identifying the connections between economic freedom and entrepreneurship is the keystone to understanding the differences between the levels of economic development of the countries. Starting from the premise of limited knowledge, we admit the importance of a vision both the specialty literature and on the reality reflected by the existing statistical data. The goal of this article is to exemplify the connection between economic freedom and entrepreneurship. The limitations of this article are evident based on two considerations: the relatively small size of the sample subject to analysis on the one hand, and the adopted approach (i.e. data observation) on the other hand. This research endeavour reiterates the importance of economic freedom for stimulating entrepreneurs and, implicitly, for economic growth. Promoting economic freedom is the keystone of entrepreneurial activity, and this aspect is illustrated in the eleven countries comprised in the sample.

\section{Literature review}

The entrepreneurial activity is centred on the individual, and how the latter acts within the market results in profit or loss. The context in which the individual acts can influence their behaviour and, implicitly, the results they achieve. The economic literature focused its attention to the way institutions and policies influence the entrepreneurial activity. Mises argues that freedom constitutes the environment in which the individual acts, having the possibility to choose between different courses of action (Mises, 2018 [1949], p. 280). To clear things up, he defines freedom as that state of affairs in which the individual's discretion to choose is not constrained by government violence beyond the margin within which the praxeological law restricts it anyway (Mises, 2018 [1949], p. 281). Significant references to the matter at hand are also found in Baumol (Baumol, 1996) and North (North, 1990). Baumol stated that one of the primary determinants of entrepreneurial behaviour, in a specific time and space, are the rules of the game. Thus, there are situations in which latter favour a focus towards a specific activity rather than another. In this context, the entrepreneurs' decisions will be guided towards entrepreneurial activities that provide a higher chance to make a profit (Baumol, 1996, p. 6). Improving the quality of institutions ultimately determines a shift in focus from unproductive or underproductive activities to productive ones that generate welfare (Baumol, 1996). North states that institutions and rules are the engine of society. Institutions can be formal and informal, but whatever form they may take, they contribute to a specific entrepreneurial behaviour. Thus, entrepreneurs adapt their strategies in order to benefit from existing opportunities or to take into account the existing limitations in the society in which they operate (North, 1990).

Building on the aforementioned opinions, we acknowledge the importance of entrepreneurial activity and the framework in which the entrepreneur operates. Therefore, we believe that economic freedom is one of the primary vectors in respect of attaining economic performances. By economic freedom we mean market-oriented institutions and policies. This topic was often approached in the specialty literature, which has revealed the importance of economic freedom in view of stimulating the activity of entrepreneurs. Empirical studies have brought to light the existence of a significant connection between entrepreneurship and economic freedom. Sobel et al. have studied a sample comprising 22 
countries and found a positive relation between the level of economic freedom and the overall entrepreneurial activity, as well as the fact that the degree of regulation is a fundamental determinant for the rates of entrepreneurial activity (Sobel, R.S., Clark, J.R., Lee, D., 2007). Campbell and Rogers use an OLS model of net business formation and economic freedom and, consistent with existing studies in the literature, conclude that the existence of a higher degree of economic freedom determines a more intense entrepreneurial activity (Campbell, N.D., Rogers, T.M., 2007). A similar position is adopted by Nyström, as the results of the empirical study carried out by the latter prove that low levels of involvement of the governmental sector, a better legal structure and the security of property rights, as well as looser regulation of lending, labour and enterprises tend to boost the entrepreneurial spirit (Nyström, 2008). Following their own studies, Reynolds et al. (Reynolds, P.D., Miller, B., Maki, W.R., 1995) argue that a third of the economic growth can be explained by the entrepreneurial activity.

In accordance with the aforementioned, Bjørnskov and Foss pointed out that government involvement has a negative impact on entrepreneurship (Bjørnskov, C., Foss, N.J., 2008). Angulo-Guerro et al. consider that economic freedom encourages entrepreneurship as a discovery of opportunities and encourages entrepreneurship as necessity (Angulo-Guerrero, M.J., Pérez-Moreno,S. Abad-Guerrero, I.M., 2017). Wennekers et al. explain the variations in the level of entrepreneurship in different countries based on cultural and institutional differences (Wennekers, S., Uhlander, L. M., \& Thurik, R., 2002) (Wennekers, S., Thurik, R., 1999). After conducting a specialty literature review, we identified an unanimously accepted opinion, namely that there is a direct connection between entrepreneurship and economic freedom. Building on the existing opinions, we set out to highlight the situation found in 11 countries in the former Eastern (communist) Bloc that are currently members of the European Union.

\section{Methodology}

This article aims to exemplify the connection between economic freedom and entrepreneurship. In order to achieve this goal, we have conducted a review of the specialty literature approaching the proposed topic and opted to highlight it using statistical data that analyse entrepreneurship, on the one hand, and the degree of economic freedom, on the other hand. The collected data refers to the year 2019 and is provided by Global Entrepreneurship Development Institute and The Heritage Foundation. Global Entrepreneurship Index provides information on the entrepreneurial skills, attitude towards entrepreneurship and aspirations of citizens in the analysed countries. Freedom Index is focused on analysing the business environment and the other factors that influence it. Of the important aspects, we mention observation of property rights, different types of freedoms, etc.

\section{Results and Discussions}

The issue of economic freedom has preponderantly marked a series of countries that have been under the communist regime for a long time. Under such circumstances, the transition to a market economy and, implicitly, the conduct of entrepreneurial actions has been a challenge. Thus, we set out to depict the current situation in 11 former USSR 
countries in Europe that have joined the European Union. The analysed sample includes the following countries: Bulgaria, Croatia, Czech Republic, Estonia, Hungary, Latvia, Lithuania, Poland, Romania, Slovakia, and Slovenia.

Table 1. Economic Freedom for the selected countries, 2019

\begin{tabular}{|c|c|c|c|c|c|c|c|c|c|c|c|c|c|}
\hline Country & PR & $\mathbf{J E}$ & GI & TB & GS & FH & BF & LF & MF & $\begin{array}{l}\mathbf{T} \\
\mathbf{F}\end{array}$ & $\begin{array}{l}\mathbf{I} \\
\mathbf{F}\end{array}$ & $\begin{array}{l}\mathbf{F} \\
\mathbf{F}\end{array}$ & $\begin{array}{c}\text { TOTA } \\
\text { L }\end{array}$ \\
\hline \multirow[b]{2}{*}{ Bulgaria } & 62. & 41. & 35. & 90. & 63. & 98. & 62. & 68. & 88. & & 7 & & \multirow[b]{2}{*}{69.0} \\
\hline & 5 & 9 & 1 & 2 & 9 & 8 & 7 & 4 & 0 & 86 & 0 & 60 & \\
\hline \multirow[b]{2}{*}{ Croatia } & 66. & 42. & 38. & 66. & 33. & 85. & 60. & 44. & 78. & & 7 & & \multirow[b]{2}{*}{61.4} \\
\hline & 0 & 9 & 6 & 4 & 4 & 4 & 7 & 0 & 5 & 86 & 5 & 60 & \\
\hline \multirow{2}{*}{\begin{tabular}{l|} 
Czech \\
Republic
\end{tabular}} & 74. & 47. & 52. & 82. & 52. & 97. & 72. & 78. & 81. & & 8 & & \multirow[b]{2}{*}{73.7} \\
\hline & 8 & 6 & 1 & 6 & 1 & 6 & 4 & 1 & 5 & 86 & 0 & 80 & \\
\hline \multirow[b]{2}{*}{ Estonia } & 81. & 76. & 73. & 79. & 51. & 99. & 75. & 57. & 79. & & 9 & & \multirow[b]{2}{*}{76.6} \\
\hline & 5 & 0 & 1 & 9 & 1 & 8 & 3 & 2 & 6 & 86 & 0 & 70 & \\
\hline \multirow[b]{2}{*}{ Hungary } & 60. & 45. & 35. & 78. & 31. & 85. & 61. & 64. & 81. & & 8 & & \multirow[b]{2}{*}{65.0} \\
\hline & 9 & 2 & 3 & 6 & 7 & 0 & 1 & 7 & 8 & 86 & 0 & 70 & \\
\hline \multirow[b]{2}{*}{ Latvia } & 67. & 48. & 35. & 77. & 57. & 96. & 77. & 73. & 81. & & 8 & & \multirow[b]{2}{*}{70.4} \\
\hline & 3 & 4 & 5 & 0 & 1 & 9 & 5 & 3 & 1 & 86 & 5 & 60 & \\
\hline \multirow[b]{2}{*}{ Lithuania } & 73. & 61. & 47. & 86. & 65. & 97. & 75. & 63. & 84. & & 8 & & \multirow[b]{2}{*}{74.2} \\
\hline & 6 & 2 & 8 & 4 & 1 & 3 & 2 & 6 & 6 & 86 & 0 & 70 & \\
\hline \multirow{2}{*}{ Poland } & 62. & 44. & 49. & 74. & 48. & 86. & 65. & 63. & 82. & & 8 & & \multirow[b]{2}{*}{67.8} \\
\hline & 3 & 0 & 8 & 9 & 8 & 4 & 4 & 9 & 1 & 86 & 0 & 70 & \\
\hline \multirow{3}{*}{ Romania } & 66. & 51. & 39. & 89. & 69. & 89. & 63. & 64. & 82. & & 7 & & \multirow[b]{2}{*}{68.6} \\
\hline & 7 & 9 & 8 & 7 & 0 & 3 & 1 & 5 & 7 & 86 & 0 & 50 & \\
\hline & 68. & 37. & 37. & 78. & 46. & 87. & 61. & 53. & 78. & & 7 & & \multirow[b]{2}{*}{65.0} \\
\hline Slovakia & 5 & 2 & 7 & 6 & 1 & 2 & 3 & 4 & 6 & 86 & 5 & 70 & \\
\hline & 76. & 46. & 53. & 58. & 38. & 82. & 79. & 61. & 83. & & 7 & & \\
\hline Slovenia & 4 & 5 & 6 & 4 & 3 & 6 & 3 & 2 & 6 & 86 & 0 & 50 & 65.5 \\
\hline
\end{tabular}

Source: author's processing using data available on The Heritage Foundation, 2019

Abbreviations:

\begin{tabular}{|l|l|l|l|l|l|}
\hline PR & Property rights & JE & Judicial Effectiveness & GI & Government Integrity \\
\hline TB & Tax burden & GS & Government Spending & FH & Fiscal Health \\
\hline BF & Business Freedom & LF & Labour Freedom & MF & Monetary Freedom \\
\hline TF & Trade Freedom & IF & Investment Freedom & FF & Financial Freedom \\
\hline
\end{tabular}

The degree of economic freedom registers values on a scale from 0 to 100 , where 0 represents a society deprived of freedom, while 100 indicates the highest level of freedom. Table 1 illustrates the values of economic freedom registered in 2019 by the 11 countries in the sample. The highest economic freedom scores are registered by two Baltic countries (Estonia and Lithuania), which opened to competition, reduced the extent of governmental involvement in the economy, and developed an independent legal system. For some states, such as Slovakia and Slovenia, the marks of the communist regime are still difficult to erase, having some issues in the Rule of Law category (judicial effectiveness and government integrity). Although the economic freedom scores were overall moderate, Bulgaria, Croatia, Hungary, and the Czech Republic draw our attention via similar issues to the ones mentioned above, particularly related to the legal system. Corruption is one of the main challenges that both the states mentioned above and Romania are faced with. The Czech Republic and Estonia reduced red tape barriers to draw foreign 
investments. Poland is one of the most important beneficiaries of subsidies granted by the European Union, which also resulted in a relatively open attitude towards foreign investors. Moreover, Estonia focused its efforts on reducing the rate of unemployment, while Latvia and Lithuania streamlined the incorporation procedure for new companies.

In the case of the analysed sample, economic freedom remains a stringent issue, with major implication for economic development. However, it is important to appreciate the evolution of the Baltic States, which chose to move away from the habits and customs of the former regime. The public policies in these states focused on economic freedom, open and competitive markets, free trade, protection of private property rights, etc. The transition to a free economy based on principles other than familiar ones is, however, a difficult process, but it cannot be omitted from discussions on entrepreneurship.

Table 2. Global Entrepreneurship Index for selected countries, 2019

\begin{tabular}{|c|c|c|c|c|c|c|c|c|}
\hline Country & GEI & $\begin{array}{c}\text { Attitudes } \\
\text { ATT }\end{array}$ & $\begin{array}{c}\text { Abilities } \\
\text { ABT }\end{array}$ & $\begin{array}{c}\text { Aspirations } \\
\text { ASP }\end{array}$ & $\begin{array}{c}\text { ATT } \\
\text { Rank }\end{array}$ & $\begin{array}{c}\text { ABT } \\
\text { Rank }\end{array}$ & ASP Rank & $\begin{array}{c}\text { GEI } \\
\text { Rank }\end{array}$ \\
\hline Bulgaria & $\mathbf{3 0 . 1}$ & 32.4 & 26.5 & 31.3 & 62 & 73 & 57 & $\mathbf{6 1}$ \\
\hline Croatia & $\mathbf{3 6 . 1}$ & 32.0 & 31.8 & 44.5 & 64 & 53 & 40 & $\mathbf{4 9}$ \\
\hline Czech Republic & $\mathbf{4 3 . 5}$ & 34.7 & 42.6 & 53.1 & 53 & 37 & 32 & $\mathbf{4 0}$ \\
\hline Estonia & $\mathbf{5 7 . 8}$ & 68.0 & 50.8 & 54.8 & 11 & 28 & 27 & $\mathbf{2 2}$ \\
\hline Hungary & $\mathbf{4 6 . 2}$ & 36.1 & 48.7 & 53.8 & 48 & 31 & 29 & $\mathbf{3 3}$ \\
\hline Latvia & $\mathbf{3 9 . 3}$ & 38.2 & 42.5 & 37.3 & 40 & 38 & 51 & $\mathbf{4 5}$ \\
\hline Lithuania & $\mathbf{4 4 . 1}$ & 35.5 & 46.9 & 49.8 & 49 & 34 & 35 & $\mathbf{3 7}$ \\
\hline Poland & $\mathbf{4 9 . 5}$ & 55.4 & 47.2 & 45.9 & 24 & 33 & 38 & $\mathbf{2 9}$ \\
\hline Romania & $\mathbf{3 8 . 6}$ & 34.7 & 33.7 & 47.6 & 54 & 48 & 36 & $\mathbf{4 6}$ \\
\hline Slovakia & $\mathbf{4 2 . 6}$ & 36.4 & 40.5 & 51.1 & 45 & 41 & 34 & $\mathbf{4 1}$ \\
\hline Slovenia & $\mathbf{5 6 . 5}$ & 56.5 & 57.6 & 55.4 & 23 & 23 & 26 & $\mathbf{2 3}$ \\
\hline
\end{tabular}

Source: author's processing using data available on Global Entrepreneurship Development Institute, 2019

To obtain a real picture of entrepreneurship, we believe it is relevant to use statistical data that reflect the entrepreneurial dimension. To this end, we chose to analyse the entrepreneurial activity of individuals in the 11 countries by looking into and processing the data available at the Global Entrepreneurship Development Institute. The Global Entrepreneurship Index structures entrepreneurship based on three dimensions: attitudes, abilities, and aspirations. In its turn, each dimension comprises sub-dimensions the main goal of which is to provide a clear picture of how individuals report to entrepreneurship. For the sake of clarity, we acknowledge the importance of listing the sub-dimensions of each main component:

(1) Attitudes refers to aspects such as: Opportunity Perception, Start-up Skills, Risk Acceptance, Networking and Cultural Support.

(2) Abilities analyses: Opportunity Start-up, Technology Absorption, Human Capital, and Competition.

(3) Aspirations focuses on: Product Innovation, Process Innovation, High Growth, Internationalization and Risk Capital.

Table 2 illustrates the scores obtained by the countries in the study sample for the three sub-dimensions, as well as their international level ranking. Estonians' attitudes focused on the conduct of entrepreneurial activities score net superior values, unlike those of other citizens in the analysed countries. With a 68/100 score, in terms of entrepreneurial attitude Estonians can be viewed as focused on discovering entrepreneurial opportunities, 
accepting risk and, moreover, having a cultural support that stimulates the opening of new businesses. At an international level, Estonia is ranked $11^{\text {th }}$ in the ranking of entrepreneurship-oriented attitudes. Slovenians and Poles can be included in the same category, scoring 56.5/100 and 55.4/100, respectively. Croats and Bulgarians are at the other end of the spectrum, having the least entrepreneurship-oriented attitudes and scoring 32/100 and 32.4/100, respectively.

Skills are another factor of major importance in the conduct of entrepreneurial activities. This time, the highest scores in this category are found in the Slovenian population, with a 57.6/100 score. Slovenians are joined by Estonians, with a 50.8/100 score. Judging by entrepreneurial skills, these two countries are ranked 23rd and 28th, respectively, at an international level. Here too Bulgarians and Croats maintain their less entrepreneurial status, even in terms of skills, with scores of 26.5/100 and 31.8/100, respectively, alongside Romania with a 33.7/100 score.

Entrepreneurial aspirations analyse the capacity to innovate, to take upon oneself the decision to internationalise a business, etc. The most focused towards such perspectives are Slovenians, Estonians, and Hungarians, with scores of 55.4/100, 54.8/100 and $53.8 / 100$, respectively, and ranked 26th, 27th and 29th at an international level. Bulgarians and Latvians are the opposite, that is the most reserved in terms of such aspirations, and they scored 31.3/100 and 37.3/100.

The shift from a socialist paradigm to capitalism engendered a series of challenges for the states in the studied sample. The implications of economic freedom on entrepreneurship cannot be omitted from any analysis. To this end, we think it is worth providing a brief illustration of the connection between the two components (see Chart 1).

Chart 1. Economic Freedom vs. Global Entrepreneurship Index for selected countries, 2019

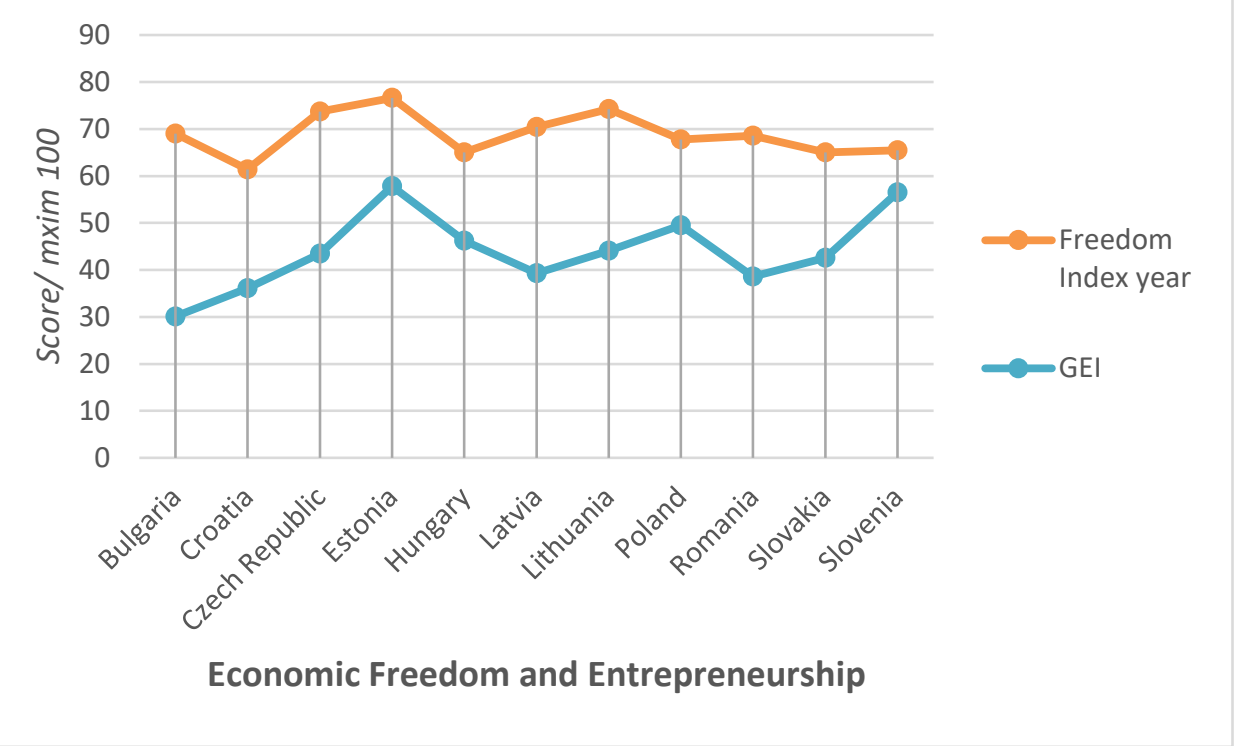

Source: author's processing using data available on The Heritage Foundation and Global Entrepreneurship Development Institute, 2019

The Baltic States stand out by their wish for reform, which determined an intense championing of liberal institutions and, implicitly, of entrepreneurship. The Doing 
Business reports deem the Baltic States as having resilient financial systems, capable to stimulate entrepreneurship. In 2020, according to the same report, Lithuania ranked 11th of 190 countries (81.6/100 points), Estonia ranked 18th (80.6/100 points) and Latvia ranked 19th (80.3/100 points) (WorldBank, 2020). At the other end of the spectrum are Bulgaria and Croatia, with lower values of economic freedom and the Global Entrepreneurship Index. The measures that would fundamentally help increase the level of economic freedom would refer to implementing a set fiscal reforms to reduce governmental spending and facilitate the operation of the legal system, as well as that of the labour market. The challenges these states are faced with are augmented by a high level of migration, ageing population, etc. The observations made for the 11 former USSR states are consistent with existing studied in the specialty literature, which argue the existence of a strong connection between economic freedom and entrepreneurship.

\section{Conclusions}

The activity of entrepreneurs requires a stable framework based on economic freedom, a framework that motivates them in their pursuit of profitable opportunities. In former USSR states, the focus towards entrepreneurial activities has been annihilated to a large extent during the communist period, and the acquisition of entrepreneurial behaviours is rather difficult. In this context, based on the analysed sample, we aimed to identify the way economic freedom stimulates entrepreneurship. After conducting a specialty literature review, we made a synthesis of the data regarding entrepreneurship and economic freedom in order to observe the current situation. The study is indeed limited by the size of the sample subject to analysis on the one hand, and the adopted approach - i.e. solely data observation - on the other hand; however, our future endeavours will also have us resort to statistical analysis in view of empirical argumentation.

The problems caused by the transition are still visible in certain states. However, countries such as Estonia and Latvia managed to catch up and reduce the level of influence of governmental structures in view of promoting an open attitude towards the free market, competition, and entrepreneurship. At the other end of the spectrum we have states such as Bulgaria and Croatia, where deficits still exist in eliminating the influence of the states and acquiring economic freedom.

In conclusion, we would like to reiterate the importance of economic freedom for stimulating entrepreneurs and, implicitly, for economic growth. Promoting economic freedom is the keystone of entrepreneurship, and the differences between countries illustrate, to a large extent, the capacity to waive short-term benefits in favour of long-term benefits.

\section{References}

1. $\quad$ Acs, Z., Szerb, L., Lloyd, A., 2018. The Global Entrepreneurship Index, Washington: The Global Entrepreneurship and Development Institute.

2. $\quad$ Acs, Z., Szerb, L., Lloyd, A., 2019. The Global Entrepreneurship Index, Washington: Global Entrepreneurship Development Institute. 
3. Acs, Z., Szerb, L., Lloyd, A., 2018. The Global Entrepreneurship Index. Technical Annex, Washington: The Global Entrepreneurship and Development Institute.

4. Angulo-Guerrero, M.J., Pérez-Moreno,S. Abad-Guerrero, I.M., 2017. How economic freedom affects opportunity and necessity entrepreneurship in the OECD countries. Journal of Business Research, 73(1), pp. 30-37. https://doi.org/10.1016/j.jbusres.2016.11.017

5. Baumol, W., 1996. Entrepreneurship: Productive, Unproductive and Destructive. Journal of Business Venturing, 11(1), pp. 3-22. https://doi.org/10.1016/0883-9026(94)00014-X

6. Bjørnskov, C., Foss, N.J., 2008. Economic Freedom and Entrepreneurial activity: Some Crosscountry Evidence. Public Choice, Volume 134 , pp. 307-328. https://doi.org/10.1007/s11127-007-9229-y

7. Campbell, N.D., Rogers, T.M., 2007. Economic Freedom and Net Business Formation. Cato Journal, 27(1), pp. 23-36.

8. North, D. C., 1990. Institutions, Institutional Change, and Economic Performance. Cambridge: Cambridge University Press .

9. Nyström, K., 2008. The Institutions of Economic Freedom and Entrepreneurship: Evidence from Panel Data. Public Choice, Volume 136, p. 269-282 . https://doi.org/10.1007/s11127-008-9295-9

10. Reynolds, P.D., Miller, B., Maki, W.R., 1995. Explaining Regional Variation in Business Births and Deaths: U.S. 1976-88. Small Business Economics, 7(5), pp. 389-407. https://doi.org/10.1007/BF01302739

11. Sobel, R.S., Clark, J.R., Lee, D., 2007. Freedom, Barriers to Entry, Entrepreneurship, and Economic Progress. The Review of Austrian Economics, 4(221-236), p. 20. https://doi.org/10.1007/s11138-007-0023$\underline{3}$

12. Wennekers, S., Thurik, R., 1999. Linking Entrepreneurship and Economic Growth. Small Business Economics, Volume 13, p. 27-55. https://doi.org/10.1023/A:1008063200484

13. Wennekers, S., Uhlander, L. M., \& Thurik, R., 2002. Entrepreneurship and its Conditions: A Macro Perspective. International Journal of Entrepreneurship Education, 1(1), p. 25-64. http://hdl.handle.net/1765/15876 EY NG NO This article is an open access article distributed under the terms and conditions of the
Creative Commons Attribution - Non Commercial - No Derivatives 4.0 International License. 